\title{
Assessing the surface water resources management for agricultural activities in the Soc Trang Province, Vietnamese Mekong Delta, Vietnam
}

\author{
Đánh giá công tác quản lý nguồn tài nguyên nước mặt cho sản xuất nông nghiệp tại tỉnh Sóc \\ Trăng, đồng bằng sông Cửu Long, Việt Nam
}

\author{
NGUYEN Thi My Linh ${ }^{1,2} *$; PHAN Ky Trung ${ }^{1}$; NGUYEN Van Be ${ }^{1}$; VAN Pham Dang Tri \\ ${ }^{1}$ College of Environment and Natural Resources, Can Tho University, Campus 2, 3/2 Street, Xuan Khanh Ward, Ninh Kieu District, Can Tho City; \\ ${ }^{2}$ Department of Engineering - Technology - Environment, Can Tho College, 30/4 Street, Hung Loi Ward, Ninh Kieu District, Can Tho City, Vietnam
}

\begin{abstract}
Climate change has been affecting to livelihoods of communities in the coastal plain of the Vietnamese Mekong Delta (VMD). Surface water management in the coastal plain was considered to be limited, especially in enforcement. Therefore, the research aimed to assess the stakeholder involvement, identify the conflict in using the surface water and mechanism to solve and avoid the conflict. The directive interview farmers and governmental staffs was implemented to collect the necessary data. The descriptive statistic was applied in order to analyze the collecting data through farmer survey. The questionnaire was built based on the governance assessment framework "Ten-building Block". The results showed that the governmental group (including the people committee and the Provincial department) was the highest participatory in the management process both in decision-making level and interested level. The surface water users, especially the farmers participated with the average rate because of their low capacity in making the decision for a new policy or a new agricultural model. Besides, different groups of stakeholders as the non-governmental organization and governmental organization (the local Youth Union, Famer's and Women's Association) played an important role in raising the water user's awareness. The remaining group, including nonagricultural company or traders, nearly were not concerned about the surface water changes. In addition, there were two main types of conflicts identified: between the farmers in the same kind (1) and different kind (2) of cultivation. As the consequence of the natural salinity and the impacts of output water from shrimp pond to the rice cultivation zone, the conflict was about the inefficient water regulation and distribution for each water user. These conflicts were mostly solved through self-negotiating and self-engaging between the farmers. In fact, there was no rule or principle to solve and prevent the potential water use conflict. Thus, this could be a great challenge for the surface water management in the agricultural zone as Soc Trang in the context of increasing the extreme climatic phenomenon.
\end{abstract}

Biến đổi khí hậu đã và đang tác động lớn đến sinh kế của các cộng đồng ven biển đồng bằng sông Cứu Long (ĐBSCL). Công tác quản lý tổng hợp tài nguyên nước mặt tại vùng ven biển được cho rằng còn tồn tại nhiều hạn chế, nhất là trong triển khai và thực thi. Vì vậy, nghiên cứu được thực hiện tại Sóc Trăng (một tỉnh ven biển ĐBSCL) nhằm đánh giá sự tham gia của các thành phần có liên quan, xác định các mâu thuẫn trong sử dụng nguồn nước mặt cũng như các giải pháp giải quyết và phòng tránh mâu thuẫn. Phương pháp phỏng vấn trực tiếp nông hộ, tham vấn chuyên gia quản lý và thống kê mô tả được áp dụng để đánh giá các mục tiêu đặt ra của đề tài. Các thông tin khảo sát được xây dựng dựa trên bộ mười tiêu chí đánh giá quản trị tài nguyên nước (van Rijswick et al., 2014). Kết quả cho thấy nhóm chính quyền địa phương (bao gồm UBND và các Sở/Ngành) có vai trò và mức độ tham gia cao nhất trong chu trình quản lý. Người sử dụng nước mặt, nhất là nông dân đóng góp sự tham gia tương đối do mức đô ra quyết định về thiết lập chính sách và lựa chọn mô hình canh tác thấp. Mặt khác, các nhóm đối tượng khác như các tổ chức phi chính phủ, Đoàn thể, Hội nông dân và Hội phụ nữ đóng góp vai trò quan trọng trong nâng cao nhận thức và kêu gọi cộng đồng sử dụng hiệu quả nguồn nước mặt. Các nhóm tổ chức kinh tế như doanh nghiệp, tiểu thương gần như không quan tâm đến nguồn nước mặt. Bên cạnh đó, các mâu thuấn về sử dụng nước mặt cũng được xác định. Các mâu thuẫn được phân chia thành 2 nhóm: cùng loại hình canh tác và giữa các loại hình canh tác khác nhau. Các mâu thuẫn chủ yếu về vấn đề điều tiết nguồn nước không hợp lý và thiếu cân bằng trong phân phối nước ngọt cho các đơn vị canh tác do xâm nhập mặn tự nhiên, xả thải nước mặn vào vùng ngọt và khai thác không đồng đều. Các mâu thuẫn này chủ yếu được giải quyết thông qua thương lượng và thỏa thuân giữa các đối tượng có liên quan chứ chưa có bất kỳ một cơ chế hay quy định nào nhằm giải quyết cũng như phòng tránh các mâu thuẫn tiềm tàng. Vi vậy, đây sẽ là một thách thức lớn cho công tác quản lý nguồn nước mặt tại vùng sản xuất nông nghiệp thâm canh như Sóc Trăng trong bối cảnh gia tăng cực đoan khí hậu. 
Keywords: agriculture, coastal zone, conflict, surface water management, stakeholder involvement

\section{Introduction}

The Vietnamese Mekong Delta (VMD) is located at the downstream end of the Mekong River basin which is considered to be the biggest fertile rice bowl of Vietnam and play a crucial role in the national food supply (Tuan, 2010). The intensive farming system has come at an increase of pressure and risk on surface water resources (Soc Trang Provincial Department of Natural Resources and Environment, 2010). Water problems mainly involve in even water distribution to rice farming areas located upstream and in conflicts related to farming practices among the various agricultural production models applied in downstream and coastal areas (Nhan et al., 2007).

Soc Trang is an agricultural and coastal province in the VMD where rice cultivation is a major economic activity (Ministry of Agriculture and Rural Development, 2016). In this area, the hydrological regime is relatively complex due to the dominance of the semidiurnal tidal cycle in the East Sea and the upstream flow (Anh et al., 2010; Dat et al., 2012; An et al., 2014; Trung et al., 2015a). In recent years, climate change has been detrimental to the surface water resources; salinity intrusion, fresh water scarcity and tidal effects are major issues and tend to become more and more severe (Wassmann et al., 2004; Bình et al., 2012; Smajgl et al., 2015); also, those influence the provincial farming system negatively (Trí et al., 2008; Hoàng et al., 2014). According to studies conducted by Quỳnh et al. (2015) and Trung et al. (2015), the water resources management in Soc Trang was limited in the coherence of applying management tools. In addition, conflicts in water use among farmer households caused by inadequate water management practices of the local people have been identified, which leads to water pollution and pathogen spread (Khánh et al., 2015). This study, therefore, was conducted to evaluate the implementation and effectiveness of surface water resources management in terms of: (1) stakeholder participation; (2) conflicts in surface water use and management; and (3) conflict prevention and resolution for surface water use.

\section{Methodology}

\subsection{Secondary data collection}

Secondary data (Table 1) includes summary reports on agricultural production, surface water management collected from Soc Trang Provincial People's Committee (PC), Soc Trang Provincial Department of Agriculture and Rural Development (DARD), Soc Trang Provincial Department of Natural Resources and Environment (DONRE), and District DARD.

\section{Table 1. Secondary data}

\begin{tabular}{llll} 
No. & Collected data & Year & Source \\
\hline $\mathbf{1}$ & $\begin{array}{l}\text { Geographic location, natural conditions, socio-economic condi- } \\
\text { tions of Soc Trang province }\end{array}$ & 2016 & Soc Trang Provincial PC \\
2 & Policies, regulations applied for surface water management & $2013-2016$ & Soc Trang Provincial DARD \\
3 & Annual report of surface water resources & $2013-2016$ & Soc Trang Provincial DONRE
\end{tabular}

\subsection{Primary data collection}

Direct interviews are utilized to gain information of the local residents about their participation and perspective in the surface water management process and possible difficulties/conflicts in surface water extraction for agricultural activities in the districts of Nga Nam, Long Phu, My Xuyen and Vinh Chau (Figure 1). Besides, the surface water management staffs are also interviewed by Key Informant Panel (KIP) approach to get data about general surface water management, role and responsibility of local government and other stakeholders in the management process.

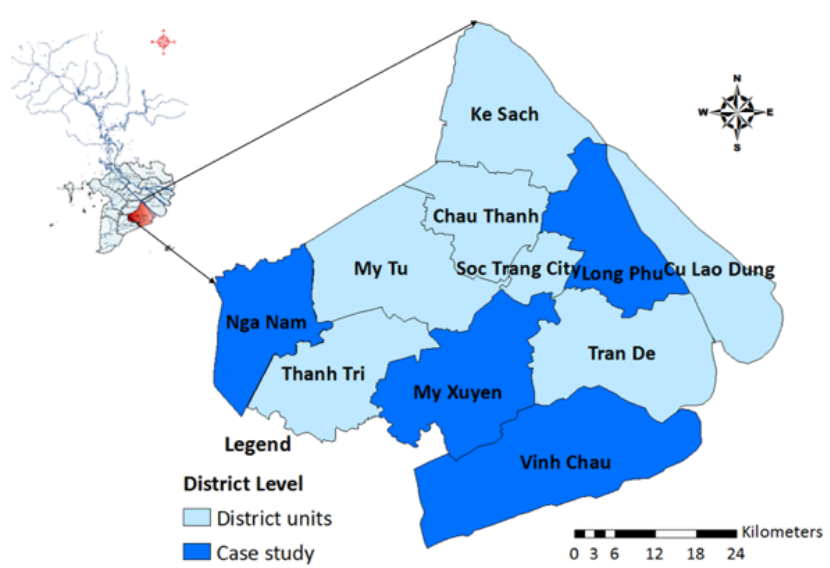

Figure 1. Location of Soc Trang province and study areas

A closed questionnaire was conducted to interview local residents and KIP interviews with the management staffs are done based on an open questionnaire that both based

ISSN 2193-6471


on the Ten building blocks water resources management assessment framework for sustainable water governance (van Rijswick et al., 2014). The contents of the framework are shown in Figure 2.

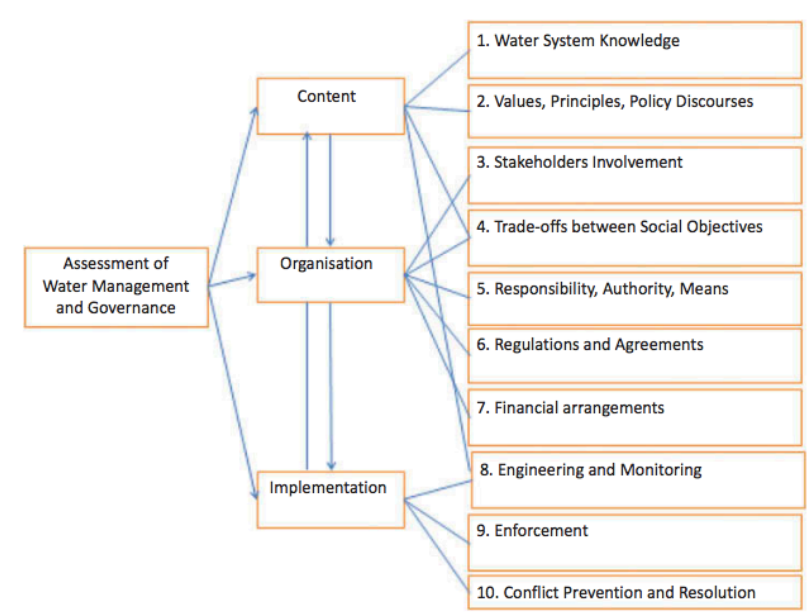

The criteria in Block 3: stakeholders' involvement; Block 5: responsibility, authority, means; and Block 10: conflict prevention and resolution of the framework were used as the research question for each objective and the basis for building the questionnaire. These blocks were chosen depending on the research's objectives. In other words, they are the baseline to deploy, analyze and carry out the objectives. Criteria for target areas and amount of survey are shown in Table 2.

Figure 2. Contents of Ten-building Block Framework

\section{Table 2. Criteria for collecting primary data}

No Content

1 Location of interviewee

2 Farmer: irrigation approaches

3 Type of agricultural cultivation

4 Governmental staffs
Selection criteria

- Located in different agro-ecological zones

- $\quad$ Specialized in rice

- $\quad$ Specialized in aquaculture

- Intercropping (rice crops, rice-shrimps, etc.)

- Vegetable crops

- $\quad$ Self-sufficient cultivation (self-watering)

- Agricultural cooperatives association

- $\quad$ Soc Trang Provincial DARD

- 4 District DARDs

- 4 District People Committees
Number of interviewees

agricultural cultivation, groundwater plays a great role in domestic consumption and water supply processes. By focusing on water relating to agricultural activities in the province, the study is going to evaluate the following aspects of surface water management.

\subsubsection{Stakeholder's participation}

Relevant stakeholders involved in surface water resources management are relatively diversified in the subject. Depending on the KIP interview result, participants are divided into five groups (Figure 3): local authorities, government administrative agencies, facilitators, users and scientific groups. Local authorities are mainly responsible for making decisions on regulations and policies. The administrative agencies are in charge of policy implementation, of which DARD (provincial and district level) are the major parties for implementing and advising the policy development of surface water resources management in agricultural production. NGOs and GOs (Farmers Unions and Women's Unions) play an important role in connecting different community groups in the society with the administrative agencies as well as in guideline an-
Surface water and groundwater are the two major sources supplying for local residents' demands in the Soc Trang province. While surface water is mainly used for 
nouncement. The water user groups take charge of carrying out the issued policies and collaborating with the local government in monitoring infrastructure, and directly controlling water resources changes or risks. Also, the enterprises in this group have the role of supporting the investment of farmers such as fertilizers, pesticides, seeds and investing in the establishment of example fields, etc. under the local monitoring. The water supply company, however, don't participate in the management process since their operation relating to the groundwater resources. Thus, the current trend of water management does not only focus on the socialization of management roles, but also commercialization of investing in water resources infrastructure. Water commercialization is beneficial so as to broaden the stakeholder involvement based on the increase in their interactions. Finally, the scientific groups, including international and national scientists, contribute their information and scientific research results to regional actual applications.

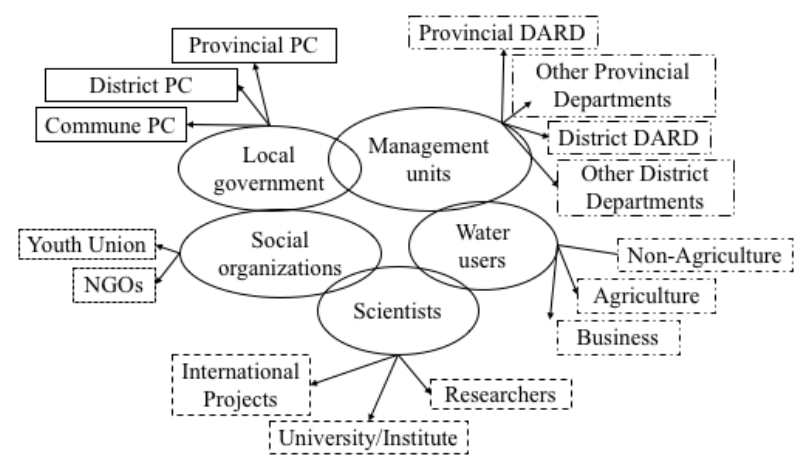

Figure 3. Stakeholders involved in surface water management

By defining the stakeholders' roles, the local authorities (People's Committees in different levels), the surface water management units in agriculture (Provincial and District DARD), farmers and organizations are considered as parties which affect and involve directly the management of surface water resources. The remaining groups are mainly responsible for linking and coordinating other departments and divisions; providing information to support environmental protection management and campaign (scientists and environmental organizations), and law enforcement on the surface water resources although they do not directly exploit the resources (nonagricultural groups) (Figure 4). This result obtained based on the KIP interview with local staffs.

In addition, the involvement of the stakeholders is markedly different (Figure 5). The level of participation of the stakeholders is based on two criteria: the level of interest and decision making. PCs at different levels and DARDs are classified as high-participation groups, for the PCs are decision makers and really interested in changes in surface water resources; DARD is the main party responsible for advising and implementing the governance of surface water resources use.

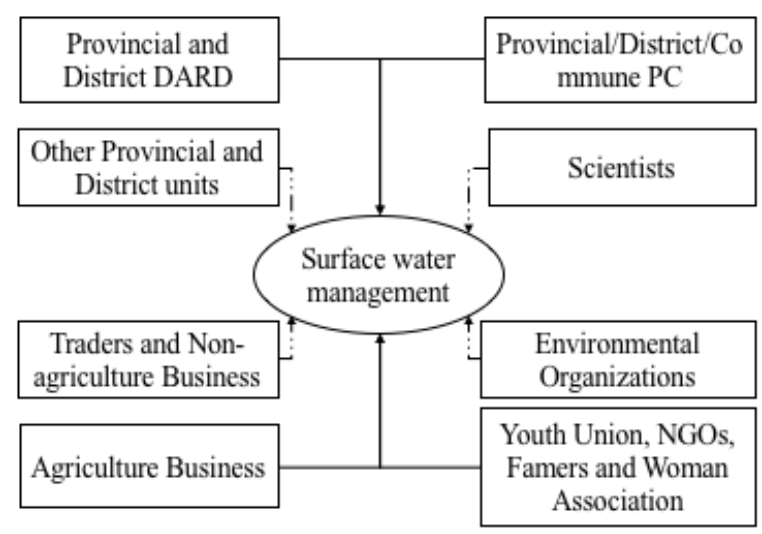

Figure 4. Interactions among the stakeholders in surface water resources management

The stakeholders who interact directly with surface water resources, comprising cooperatives using water resources for farming and farmers, are very interested in the change of surface water resources. Also, scientists studying water used in agriculture, different GOs (including Youth Union, Farmers' \& Women Association) and NGOs have a high level of interest in surface water resources. Scientists are the main party conducting research and providing important information for policy makers in order to have a basis for governance execution. NGOs and different GOs participate in the management procedure through dissemination activities and enhancement of the efficiency of surface water resources use. Other government administrative agencies and non-agricultural groups are involved to a very low extent. These parties are not in charge of or directly relevant to surface water resources leading to the low level of interest and participation.

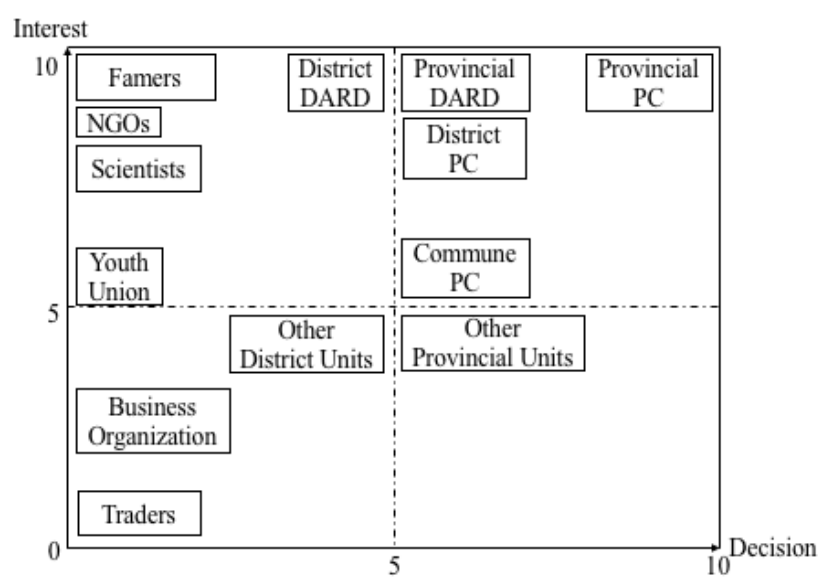

Figure 5. Level of participation of the stakeholders in surface water resources management

\subsubsection{Surface water management effectiveness}

Most interviewed farmers have never been involved in discussions or idea-exchanged with local authorities on farming systems and natural resources management. For the group of local people involved in discussions with the management units, the discussion topics are mainly on water management in the cultivation process. However, the interaction between the local people and authorities is still low due to the low number of people involved in 
the management process. Discussions with the local authorities mainly stem from the preparation of the administrative units, by directly visiting the households to invite them and call for participation. The local people are completely passive with this interactive activity.

The policy is an important tool for executing management activities. Generally, the policy is the basis for the administrative agencies to plan their management and for the users to exercise their legal responsibilities. In practice, however, the number of people accessing management tools is quite limited, potentially leading to water resources risks and a detriment to agricultural producers.

Hence, there are still many shortcomings in the application and interaction among the stakeholders (Figure 6). According to the community, despite many changes and improvements, the effectiveness of management is evaluated at a fair level, due to the fact that information discrimination, interaction and exchange which have been conducted are considered poor. The procedures for those activities were cumbersome and conducted through many stages or levels; difficulties and shortcomings encountered by local people have been recorded, but sometimes not satisfactorily resolved. Discrimination between the social sectors still exists, which leads to the level reduction of public trust in administrative agencies.

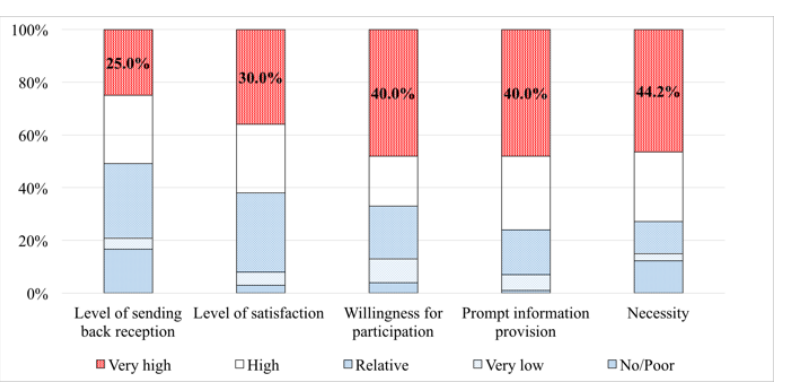

Figure 6. Community evaluation of the management effectiveness

\subsection{Water use conflicts and resolutions}

Table 3. Causes and consequences of water conflicts

\section{Conflicts}

Water balance for different types of farming

Water pumping and regulating

Water distribution to the same farming types

\subsubsection{Water use conflicts}

Agricultural farming systems are facing many difficulties. The greatest difficulty for coastal provinces, as Soc Trang Province, is the increase of salinity intrusion, particularly during the dry season, resulting in a combination of drought and water scarcity (Smajgl et al., 2015). Moreover, according to the management staffs, the impact from different farming methods in the vicinity also increases local salinity level in some localities in the province. More specifically, the staffs and farmers interviewed in Nga Nam town considered that water from shrimp ponds in the adjacent areas between Soc Trang and Bac Lieu provinces (a province bordering south of Soc Trang) discharges into and increase the salinity of canals and channels in their area. Uncertainty about the salinity impact time and duration has made the production of the localities completely passive. In addition, management mechanisms have not yet responded to and addressed the current difficulties in agricultural production. Supportive policies for farmers and surface water users are still limited.

Difficulties encountered during production phase lead to contradictions on water use. The current contradictions from water users are mainly about distributing water evenly for different agricultural areas, ensuring sufficient water for production, guaranteeing water pumping among the users is fair and feasible. Water conflicts derive from various causes and have undesirable consequences for cultivating systems (Table 3). Causes of conflicts include both nature changes and human impacts. Conflicts lead to significant impacts such as productivity reduction or crop failure, changes in physicochemical characteristics of water resources as well as imbalances in the capacity of water supply to users in the same area. These conflicts, additionally, have another big effect of splitting up the cultivating groups and causing other social disagreements.
Causes

Less water from upstream

Saline water intrusion coming deeply into the fields

Crop calendar is not simultaneous

Spontaneous production and dissimilar farming models Unplanned and inconsistent water regulation among the users

Natural conditions

Expand the cultivation area of water users Simultaneous and convergent water exploration

\section{Consequences}

Loss of sustainability and regularity from the amount of water supplied Decrease of agricultural productivity Loss of crops and natural characteristics of agricultural ecosystems

Damage and increase risk for farming models

Change water characteristics or pollute water

Reduce productivity

Imbalance in water capacity that can be used per unit of water use 


\subsubsection{Conflict prevention and resolution}

The interviewee's result showed that conflict relating to surface water use is primarily addressed through negotiation and agreement among water users. Furthermore, local authorities are in charge of a bridge to mitigate or eliminate conflicts. Therefore, the initiative and willingness of the agricultural cultivators is an important requirement in resolving conflicts and disagreements over water use. In addition, KIP results showed that government regulations or legal interventions are also used to resolve conflicts, but only in the case where conflicts are very serious or could result in serious consequences for cultivation.

The role of local managers, however, has not been clearly demonstrated through the resolution and prevention of conflicts among water users. Figure 7 presents assessments of agricultural cultivator groups on the role of administrative agencies in addressing and preventing water use conflicts. The results show a similarity with the perception that research has put forth. The level of interest, inspection of cultivation process and timely resolution of the conflicts are evaluated at a relatively moderate level. According to farmers, local authorities and administrative agencies need to pay more attention to farming practices in order to prevent the risk of conflicts in water use; particularly in the context of agricultural restructuring and the complex changes of natural conditions.

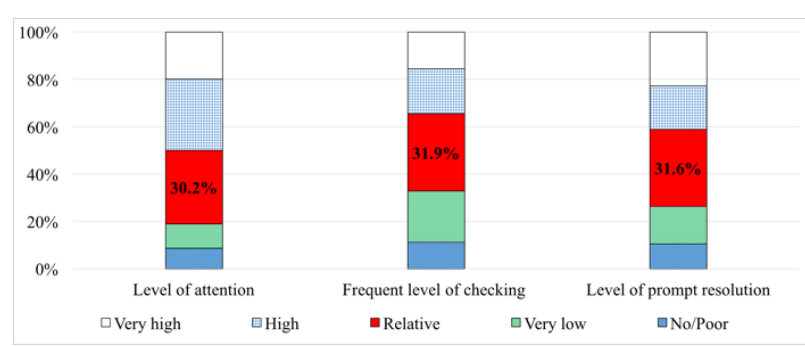

Figure 7. Cultivator evaluation of the roles of administrative agencies in water conflict resolution and prevention

\section{Conclusions}

Surface water resources management involved different stakeholders in the society. The participation level of those stakeholders, however, is greatly diverse and different among the localities. In addition, stakeholders' role has not been defined clearly and suitably. The target groups for water resources state management play a crucial role and are rated at a high level of participation; the water users are ranked at the medium level, and the non-agricultural groups play the lowest role in surface water management.

The interaction between different stakeholders is reflected to be weak. There is in short of specific regulation or a necessary basis on stakeholders' collaboration resulting in incoherent participation in the management process and tends to be a strong challenge for towards integrated surface water resources management.
Conflicts in water use are mainly from unreasonable water regulation, increased salinity intrusion and droughts which lead to water scarcity. Conflict solving mechanisms are currently limited and water risk prevention is not satisfactorily concerned. The self-solving measure is the main approach for local residents to resolve the conflict and local government shows weak function in charge of settling and preventing potential water extraction conflicts. Thus, this could be a potential cause leading to severe consequences for surface water and agricultural farming systems in the context of extreme climatic conditions.

\section{References}

[1] An, T.D., M. Tsujimura, V. Le Phu, A. Kawachi, and D.T. Ha. 2014. Chemical Characteristics of Surface Water and Groundwater in Coastal Watershed, Mekong Delta, Vietnam. Procedia Environ. Sci. 20: 712721.

[2] Anh, N.N. 2010. Master plan for water resources development in the Mekong Delta adaptation to climate change and sea level rise. 1 - 32. Conference on Delta's Times of Climate Change, Rotterdam, the Netherlands, 29 September to 01 October 2010.

[3] Ministry of Agriculture and Rural Development. 2016. Irrigation systems development in the Ca Mau Penisula to adapt with climate change. 1. Available at http://wcag.mard.gov.vn/pages/news_detail.aspx?N ewsld=12642.

[4] Hoàng, H.M, Trí, P.V.Đ, and Trung, N.H. 2014. Surface water resources management for rice farming systems in the coastal areas of the Vietnamese Mekong Delta. Can Tho University Journal of Science. 35: 90-103.

[5] Khánh, T.N., Hằng, T.T.L., Diễm, N.T.K and Trí, P.V.Đ. 2015. The management of surface water resources in agriculture and aquaculture in coastal areas in $\mathrm{Vi-}$ etnamese Mekong Delta under impacts of climate change. Can Tho University Journal of Science. Environment and Climate Change: 159-166.

[6] Trí, L.Q., Gương, V.T., Vũ, P.T., Bình, N.T.S., Kiệt, N.H., and Chiến, V.V. 2008. Evaluating the changes of soil properties and land use at three coastal districts in Soc Trang province. Can Tho University Journal of Science, 9: 59-68.

[7] Bình, N.T., Huôn, L., and Phanh, T.S. 2012. Participatory vulnerability analysis: A case study from saline intrusion in the Mekong Delta. Can Tho University Journal of Science, 24(b): 229-239.

[8] Nhan, Đ.K., Be, N.V., and Trung, N.H. 2007. Water Use and Competition in the Mekong Delta, in Tran Than Be, Bach Tan Sinh and F. Miller (eds.) Challenges to Sustainable Development in the Mekong Delta: 
Regional and National Policy Issues and Research Needs Bangkok: Sustainable Mekong Research Network (sumernet), 143-188.

[9] Quynh, T.T.T., Hằng, T.T.L, Diễm, N.T.K., and Tri, P.V.Đ. 2015. Assessment of institutional arrangement of the groundwater resources in the Soc Trang province. Can Tho University Journal of Science. (1859-2333): 234-245.

[10] van Rijswick, M., J. Edelenbos, P. Hellegers, M. Kok, and S. Kuks. 2014. Ten building blocks for sustainable water governance: an integrated method to assess the governance of water. Water Int. 39(5): 725742.

[11] Smajgl, A, Toan, T.Q., Nhan, Đ.K., Ward, J., Trung, N.H., Tri, L.Q., Tri, V.P.D. and Vu, P.T. 2015. Responding to rising sea levels in the Mekong Delta. Nature Climate Change, 5(2): 167-174.

[12] Soc Trang Provincial Department of Natural Resources and Environment. 2010. Report on groundwater resources extraction and protection long-term planning towards 2020. 151p.

[13] Dat, T.Q., Trung, N.H, and Likitdecharote, K. 2012. Modeling the influence of river discharge and sea level rise on salinity intrusion in the Mekong Delta.
Can Tho University Journal of Science, 21: 141-150.

[14] Trung, T.T. 2015a. Report on "The state and solutions for conducting a complete irrigation system responsing to develop a modern agriculture platform". $9 p$.

[15] Trung, P.K, Hang, T.T.L, Diem, N.T.K, Tri, P.V.D. 2015b. Hiện Trạng Khai Thác Sử Dụng và Quản Lý Tài Nguyên Nước Dưới Đất Tại Thị Xã Vĩnh Châu, Tỉnh Sóc Trăng. Sci. J. CanTho Univ. (1859-2333): 246253.

[16] Tuan, L.A. 2010. Impacts of climate change and sea level rise to the integrated agriculture-aquaculture system in the Mekong River Basin - A case study in the Lower Mekong River Delta in Vietnam. 1-10. International workshop on "the International Workshop on the "Climate Change Responses for Asia International Rivers: Opportunities and Challenges". China, 26-28 February, 2010.

[17] Wassmann, R., Hien, N.X., Hoanh, C.T., and Tuong, T.P. 2004. Sea level rise affecting the Vietnamese Mekong delta: water elevation in the flood season and implications for rice production. Clim. Change, 66: 89-107. 